\title{
ETNOZOOLOGI UNTUK KONSUMSI SUKU DAYAK KANAYANT DI DESA LINTAH BETUNG KECAMATAN MENYUKE KABAUPATEN LANDAK
}

\author{
(Etnozoology For Comsumption Of Dayak Kanayant In Lintah Betung Village Menyujke Distric \\ Landak Regency )
}

\author{
Yakob Richardo, Hafiz Ardian, M Sofwan Anwari \\ Fakultas Kehutanan Universitas Tanjungpura Jalan Daya Nasional Pontianak 78124 \\ E-mail: yakobrichardo@gmail.com
}

\begin{abstract}
The untilization of animal for consumption by Dayak Kanayant tribe needs to be used as data to find out the types of animals used, the patterns of utilization and the parts of organs used. One of the utilization of animals by Dayak Kanayant tribe is for consumption. This study aimed to determine the types of animals, animal parts and ways of processing animals for consumption by Dayak Kanayant tribe in Lintah Betung Village. The method used in this study was a survey method, the selection of respondents using the snowball sampling method, and data collection using questionnaire. In this study, repondents were obtained as many as 20 people consisting of 18 men and 2 women. The results showed that the use of animals for consumption needs as many as 32 species of animals consisting of mammals, aves, amphibians, pisces, reptile, crustaceans, insecta, and molluscs. The main animal usedis the class of mammals for daily cunsumption needs. Dayak Kanayant people processed animal meat by frying, cooking, and grilling. The most people still used traditional equipment to cook meat and to hunt animals.
\end{abstract}

Keyword : Comsumption, Dayak Kanayant, Etnozoology

\section{PENDAHULUAN}

Kalimantan merupakan salah satu pulau terluas di Indonesia yang kaya akan keanekaragaman flora dan fauna. Kekayaan flora dan fauna di Kalimantan dapat dipelihara sebagai bagian dari kekayaan sumber daya alam. Keberadaan flora dan fauna tidak dapat dipisahkan dengan kehidupan manusia. Tumbuhan dan hewan mempunyai manfaat besar bagi kehidupan manusia.

Masyarakat pedalaman Kalimantan atau yang dikenal dengan masyarakat Dayak mempunyai ketergantungan dengan alam sekitar yang sangat tinggi. Masyarakat Dayak memanfaatkan tumbuhan dan hewan umtuk memenuhi kebutuhan hidupnya. Pemanfaatan tumbuhan oleh masyarakat Dayak sudah banyak dikaji, namun informasi tentang pemanfaatan hewan oleh masyarakat Dayak belum banyak di ketahui. Hubungan manusia dalam memanfaatkan satwa disebut juga etnozoologi.

Orang Rimba Bukit Duabelas Kabupaten Sarolagun, memanfaatkan 65 jenis hewan liar untuk dikonsumsi (Masyithah, 2016). Masyarakat Dayak Seberuang di Kecamatan Tempunak Kabupaten Sintang, memanfaatkan 37 jenis satwa untuk dikonsumsi, pengobatan, ritual dan kesenian (Dewin, 2017). Masyarakat Dayak Belangin memanfaatkan 10 jenis spesies satwa untuk obat-obatan (Heningsih, 2018). 
Ragam pemanfaatan satwa merupakan implikasi dari beragamnya etnis, baik dalam hal jenis satwa yang dimanfaatkan, bentuk pemanfaatan maupun cara memanfaatkannya. Hal ini berkaitan erat dengan proses interaksi yang berkembang antara etnis tertentu yang tinggal di sekitar hutan dengan alam lingkungannya dari waktu ke waktu.

Salah satu etnis asli yang terdapat pada Provinsi Kalimantan Barat yaitu suku Dayak Kanayant di desa Lintah Betung, Kecamatan Menyuke, Kabupaten Landak. Masyarakat Dayak Kanayant ini juga memiliki keragaman dalam pemanfaatan fauna baik untuk dikonsumsi obat-obatan, upacara adat dan supranatural. Suku Dayak Kanayant merupakan suku yang masih menjaga budaya leluhur secara turun menurun. Salah satu budaya mereka yaitu masih memanfaatkan hewan untuk kebutuhan konsumsi, kebutuhan adat istiadat, kebutuhan pengobatan dan juga bisa dimanfaatkan sebagai simbol kesenian.

Praktek pemanfaatan satwa telah dilakukan oleh sebagian besar suku Dayak Kanayant di Kalimantan Barat untuk kebutuhan hidup sehari-hari, berburu adalah salah satu cara masyarakat Dayak dalam memperoleh hewan buruan. Berburu merupakan salah satu kegiatan penting dalam pemenuhan kebutuhan hidup mereka serta suatu bentuk dari penyesuaian diri manusia terhadap sumberdaya alam bagi masyarakat sekitar hutan yang menggantungkan hidupnya terhadap hutan (Dwi, 2011). Suku Dayak selain memanfaatkan hewan buruan juga berternak untuk kebutuhan hidup seperti berternak babi, ayam, kambing dan lainlain. Kebanyakan Suku Dayak Kanayant berternak babi karena dalam kepercayaan Suku Dayak Kanayant babi merupakan simbolis dalam beberapa upacara ritual adat dan hampir semua ritual adat Dayak Kanayant menggunakan babi dan ayam. Diperkirakan masih banyak pengetahuan lokal suku Dayak Kanayant mengenai pemanfaatan hewan yang masih berkembang hingga saat ini. Pemanfaatan terhadap satwa yang dilindungi dikhawatirkan akan mempercepat laju kepunahan satwa jika tidak dilakukan perencanaan pengelolan yang baik. Oleh sebab itu perlu adanya penelitian mengenai pemanfaatan satwa oleh masyarakat Dayak Kanayant untuk menghimpun informasi pemanfaatan satwa di daerah tersebut. Tujuan penelitian ini adalah untuk mengetahui jenis-jenis satwa, bagian satwa dan cara pengolahan satwa untuk konsumsi oleh Suku Dayak Kanayant di Desa Lintah Betung.

\section{METODE PENELITIAN}

Penelitian ini dilaksanakan di Desa Lintah Betung selama \pm 4 minggu efektif di lapangan. Penelitian dilakukan dengan metode survei dengan wawancara berbantuan kuisioner. Pada penelitian ini peneliti hanya melakukan di lingkungan pemukiman masyarakat.

\section{Teknik Pengumpulan Data}

Pengumpulan data dilakukan dengan metode survei dan wawancara terhadap responden. Pemilihan 


\begin{abstract}
responden dilakukan dengan menggunakan metode snowball sampling yaitu dengan menentukan rseponden kunci untuk kemudian menentukan responden lainnya berdasarkan informasi dari responden sebelumnya. Responden kunci adalah orang yang memiliki pengetahuan luas mengenai jenis hewan dan pemanfaatannya serta memiliki intensitas tinggi dalam pemanfaatan hewan (Rusmiati, 2018). Penelitian ini harus meminta rekomendasi calon responden dari kepala desa, kepala dusun, kepala adat, dukun, tabib, pengguna, orang tua, pemburu, ibu-ibu dan sebagainya.
\end{abstract}

\section{Analisis Data}

Data hasil wawancara yang meliputi nama jenis (nama lokal dan ilmiah), manfaat (konsumsi, ritual adat dan mistis, media berbyru, pengobatan, dan kesenian), bagian yang dimanfaatkan (daging, tulang, darah, bulu, isi perut, telur dan lain-lain), cara memperoleh (teknik, alat dan waktu), cara pengolahan berdasarkan manfaatnya dibuat dalam bentuk tabulasi dan kemudian dianalisis secara deskriptif.

\section{HASIL DAN PEMBAHASAN}

\section{Sejarah Dayak Kanayant}

Dayak Kanayatn adalah salah satu dari sekian ratus sub Suku Dayak yang mendiami Pulau Kalimantan. Dayak Kanayant tinggal di daerah daerah Kabupaten Landak, Kabupaten Mempawah, Kabupaten Kubu Raya, Kabupaten Bengkayang, serta sebagian kecil di Kabupaten Sanngau dan Kabupaten Ketapang. Dayak kanayant menggunakan bahasa Ahe atau nana' serta Damea atau Jare dan yang serumpun. Sebenarnya secara tingkatan sangat sulit untuk merinci jumlah bahasanya. Ini dikarenakan bahasa yang digunakan sarat dengan berbagai dialek dan juga logat pengucapan. Beberapa contohnya seperti orang Dayak Kanayant yang mendiami wilayah Meranti (Landak) terbagi dalam bahasa satolo-ngelampa', songga batukngngalampa', dan angkabakng-ngabukit. Percampuran dialek dan logat menyebabkan percampuran bahasa menjadi bahasa baru.

Banyak generasi Dayak Kanayant saat ini tidak mengerti bahasa yang digunakan para orangtua. Komunikasi saat ini, banyak kosa kata Indonesia yang diadopsi dan kemudian "di-Dayakkan". Bahasa yang digunakan sekarang oleh generasi muda mudah dimengerti karena mirip dengan bahasa Indonesia atau Melayu. Pengelompokan berdasarkan bahasa banana' belum sepenuhnya dapat diterima, sebab dalam kenyataannya, yang tergolong menggunakan kosa kata bahasa Kanayatn, bukan hanya dalam kelompok bahasa banana. Suku Dayak yang memiliki kesamaan kosa kata mencapai 95-98 \% sama, juga termasuk kelompok ini, walaupun bahasanya bukan disebut bahasa banana, misalnya banane hanya mengalami lapalisasi yang berbeda sedikit saja. Perbedaan hanya pada hurup 'a' (Kanayatn asli) berubah jadi 'e' (Kanayatn Banyuke), mungkin pengaruh bahasa Melayu. Bahasa di 
daerah lain, misalnya Samalantatn, 'alapm'(asli) jadi “a:apm” (Kanayant Bakati' dan Sidik-Senakin).

Religi asli Suku Dayak Kanayant tidak terlepas dari adat istiadat mereka, bahkan dapat dikatakan adat menegaskan identitas religius mereka. Orang Dayak Kanayant dalam praktik sehari-hari tidak pernah menyebut agama sebagai normativitas mereka, melainkan adat. Sistem religi ini bukanlah sistem hindu Kaharingan seperti yang dikenal oleh orang-orang pada umumnya. Orang Dayak Kanayatn menyebut Tuhan dengan istilah Jubata, dikatakan menurunkan adat kepada nenek moyang Dayak Kanayant yang berlokasi di Bukit Bawakng (sekarang masuk wilayah kabupaten Bengkayang). Mereka dalam mengungkapkan kepercayaan kepada Jubata, memiliki tempat ibadah yang disebut panyugu atau padagi. Selain itu diperlukan juga seorang imam panyangahatn yang menjadi seorang penghubung, antara manusia dengan Tuhan ( Jubata).

Suku Dayak merupakan bagian dari masyarakat adat. Masyarakat adat adalah komunitas-komunitas yang hidup berdasarkan asal usul keturunan di atas suatu wilayah adat, yang memiliki kedaulatan atas tanah dan kekayaan alam, kehidupan sosialbudayanya diatur oleh hukum adat dan lembaga adat yang mengelola keberlangsungan hidup masyarakatnya. Hukum adat Dayak Kanayatn mempunyai satuan wilayah teritorial yang dusebut binua. Binua merupakan wilayah yang terdiri atas beberapa kampung (dulunya Radakng/ Bantang). Masing masing binua punya otonominya sendiri, sehingga komunitas binua yang satu tidak dapat mengintervensi hukum adat di binua lain. Setiap binua dipimpin oleh seorang timanggong (Kepala Desa). Timanggong memiliki jajaran-bawahan yaitu Pasirah (Pengurus Adat) dan Pangaraga (Pengacara Adat). Ketiga pilar inilah yang menjadi lembaga adat Dayak Kanayant (Ngadri, 2018).

\section{Pemanfaatan Satwa Untuk Konsumsi}

Berdasarkan hasil penelitian yang dilakukan di Desa Lintah Betung diperoleh hewan yang dimanfaatkan untuk konsumsi, untuk lebih jelasnya dapat dilihat pada tabel 2. Berdasarkan hasil wawancara terdapat 32 jenis hewan yang dimanfaatkan untuk konsumsi oleh masyarakat Dayak Kanayant di Desa Lintah Betung. Bagian yang diolah adalah daging untuk cara pengolahannya lebih banyak dimasak kuah, digoreng dan dibakar. Daging merupakan sumber protein hewani yang sangat bermanfaat bagi bagi perkembangan tubuh manusia. Masyarakat Dayak Kanayant di Desa Lintah Betung dalam prakteknya daging dimanfaatkan untuk kebutuhan konsumsi namun terdapat jenis hewan yang dagingnya dapat berkhasiat sebagai obat yaitu daging ular sawah atau Phyton. Beberapa jenis satwa yang dikonsumsi dan cara pengolahannya oleh masyrakat Dayak Kanayant. 
Tabel 1. Pemanfaatan Hewan untuk Konsumsi oleh Masyarakat Dayak Kanayant di Desa Lintah Betung (Utilization Of Animals For Comsumption By Dayak Kanayant Communities In Lintah Betung Village)

\begin{tabular}{|c|c|c|c|c|c|}
\hline No & $\begin{array}{l}\text { Nama } \\
\text { Daerah }\end{array}$ & $\begin{array}{c}\text { Nama } \\
\text { Indonesia }\end{array}$ & Nama Ilmiah & $\begin{array}{c}\text { Bagian yang } \\
\text { dimanfaatkan }\end{array}$ & Cara Pengolahan \\
\hline \multicolumn{6}{|c|}{ Mamalia } \\
\hline 1 & Babi & Babi & Sus barbatus & Daging & Dimasak kuah, digoreng, dan dibakar \\
\hline 2 & Kalilawar & Kelelawar & Pteropus admiralitatum & Daging & Dimasak kuah \\
\hline 3 & Tupe & Tupai & Tupaia gracilus & Daging & Digoreng \\
\hline 4 & Tangilikng & Trenggiling & Manis javanica & Daging & Dimasak kuah \\
\hline 5 & Tikus Uma & Tikus Sawah & Rattus argentiventer & Daging & Digoreng \\
\hline 6 & Kulak-kulot & Munsang & $\begin{array}{c}\text { Paradoxurus } \\
\text { hermaphrodites }\end{array}$ & Daging & Dimasak kuah \\
\hline 7 & Anyokng & Rusa & Cervus unicolor & Daging & Dimasak kuah \\
\hline 8 & Ucing Batu & Kucing Hutan & Pardofelis marmorata & Daging & Dimasak kuah \\
\hline 9 & Asu & Anjing & Canis lupus dingo & Daging & Dimasak kuah, dibakar \\
\hline 10 & Kara & Monyet & Macaca fascicularis & Daging & Dimasak kuah \\
\hline 11 & Kijang & Kijang & Muntiacus muntjak & Daging & Dimasak kuah \\
\hline 12 & Palanuk & Kancil & Tragulus & Daging & Dimasak kuah \\
\hline 13 & Asu Itam & Anjing Hitam & Canis lupus familiaris & Daging & Dimasak kuah \\
\hline \multicolumn{6}{|c|}{ Aves } \\
\hline 14 & $\begin{array}{l}\text { Burung } \\
\text { Punai }\end{array}$ & Burung Punai & Treron capellei & Daging & Digoreng \\
\hline 15 & Manok & Ayam & $\begin{array}{l}\text { Gallus gallus } \\
\text { domesticus }\end{array}$ & Daging & Dimasak kuah, digoreng \\
\hline 16 & Karoak & Kareo Padi & $\begin{array}{l}\text { Amaurornis } \\
\text { phoenicurus }\end{array}$ & Daging & Digoreng \\
\hline 17 & Kaluakng & Kalong & Pteropus vampyrus & Daging & Digoreng \\
\hline \multicolumn{6}{|c|}{ Pisces } \\
\hline 18 & $\begin{array}{c}\text { Ikan } \\
\text { Cocokng }\end{array}$ & Ikan Betok & Anabas testudineus & Daging & Digoreng \\
\hline 19 & Ikan Bila'o & Ikan Gabus & Channa striata & Daging & Dimasak kuah digoreng \\
\hline 20 & Ikan Kale & Ikan Lele & Clarias batrachus & Daging & Dimasak kuah, digoreng \\
\hline 21 & Ikan Patek & Ikan Baung & Mystus nemurus & Daging & Dimasak kuah, digoreng \\
\hline \multicolumn{6}{|c|}{ Amfibi } \\
\hline 22 & $\begin{array}{c}\text { Rega } \\
\text { Simpakong }\end{array}$ & Kodok sawah & Fejervarya cancivora & Daging & Dimasak kuah \\
\hline \multicolumn{6}{|c|}{ Molusca } \\
\hline 23 & Kiong Mas & Keong Mas & Pomacea canaliculata & Daging & Dimasak kuah \\
\hline 24 & $\begin{array}{l}\text { Takuyukng } \\
\text { Gari }\end{array}$ & Bekicot & Achatina fulica & Daging & Digoreng \\
\hline 25 & Takuyukng & Tengkuyung & Helix pomatia & Daging & Dimasak kuah \\
\hline \multicolumn{6}{|c|}{ Crustacia } \\
\hline 26 & Karamak & Kepiting & Parathelphusa convexa & Daging & Dimasak kuah \\
\hline 27 & Ondang & Udang & $\begin{array}{c}\text { Macrobrachium } \\
\text { rosenbergii }\end{array}$ & Daging & Dimasak kuah, digoreng \\
\hline \multicolumn{6}{|c|}{ Reptil } \\
\hline 28 & Kakurak & Kura-Kura & Manouria emys & Daging & Dimasak kuah \\
\hline 29 & Biawak & Biawak & Varanus salvator & Daging & Dimasak kuah \\
\hline 30 & Ular Sawa & Ular Pithon & Phyton curtus & Daging & Dimasak kuah \\
\hline 31 & Labi & Labi-Labi & Dongania subplana & Daging & Dimasak kuah \\
\hline \multicolumn{6}{|c|}{ Intecta } \\
\hline 32 & Amatar & Ulat Sagu & $\begin{array}{l}\text { Rhynchophorus } \\
\text { ferruginesus }\end{array}$ & Daging & Digoreng \\
\hline
\end{tabular}


Berdasarkan hasil penelitian yang dilakukan di Desa Lintah Betung diperoleh hewan yang dimanfaatkan untuk konsumsi, untuk lebih jelasnya dapat dilihat pada tabel 2. Berdasarkan hasil wawancara terdapat 32 jenis hewan yang dimanfaatkan untuk konsumsi oleh masyarakat Dayak Kanayant di Desa Lintah Betung. Bagian yang diolah adalah daging untuk cara pengolahannya lebih banyak dimasak kuah, digoreng dan dibakar. Daginng merupakan sumber protein hewani yang sangat bermanfaat bagi bagi perkembangan tubuh manusia. Masyarakat Dayak Kanayant di Desa Lintah Betung dalam prakteknya daging dimanfaatkan untuk kebutuhan konsumsi namun terdapat jenis hewan yang dagingnya dapat berkhasiat sebagai obat yaitu daging ular sawah atau Phyton. Beberapa jenis satwa yang dikonsumsi dan cara pengolahannya oleh masyarakat Dayak Kanayant tersaji pada Tabel 2.

Pemanfaatan hewan untuk konsumsi oleh masyarakat Dayak Kanayant di Desa Lintah Betung salah satunya adalah daging. Daging merupakan sumber protein yang dibutuhkan masyrakat Dayak Kanayant untuk memenuhi kebutuhan protein dari daging hewan yang mereka manfaatkan untuk konsumsi tersebut.

Hati merupakan bagian organ makhluk hidup yang memilii banyak fungsi seperti meregenerasi sel darah merah, menyimpan energi, membersihkan darah dan fungsi lainnya (Putri, 2009). Masyarakat Dayak Kanayant juga memanfaatkan hati ayam dan hati babi untuk dikonsumsi dengan cara dimasak kuah dan digoreng yang sudah menjadi tradisi sejak zaman dahulu.

Masyarakat Dayak Kanayant di Desa Lintah Betung juga memanfaatkan usus ayam untuk dikonsumsi. Usuu ayam diketahui memiliki kandungan nutrisi yang baik bagi tubuh seperti manfaat protein, manfaat vitamin A, manfaat lemak, kalsium, manfaat zat besi, dan vitamin B1 sehingga dapat menambah asupan nutrisi tubuh.

Lemak babi juga dimanfaatkan masyarakat Dayak Kanayant di Desa Lintah Betung untuk dijadikan bahan konsumsi. Menurut penelitian, lemak daging babi punya kandungan gizi lebih baik tinggi dai bayam segar. Lemak babi juga merupakan sumber vitamin B dan mineral yang baik.

\section{Status Konservasi}

Status konservasi merupakan indikator yang digunakan untuk menunjukkan tingkat keterancaman kepunahan spesies makhluk hidup. Status konservasi diterapkan baik untuk hewan maupun tumbuhan. Penetapan status konservasi bertujuan untuk memberikan perlindungan dan pelestarian terhadap spesies makhluk hidup.

Status konservasi mengenai perdagangan satwa pada daftar CITES APPENDICE meliputi tiga tingkatan yaitu appendix I, appendix II dan appendix III. Appendix I adalah Satwa atau tumbuhan yang terancam punah. Perdagangan terhadap spesies ini hanya diperbolehkan dalam keadaan luar biasa satwa yang termasuk kategori ini berdasarkan penelitian yaitu Burung Enggang (Buceros vigil) dan Terengiling (Manis javanica). 
Appendix II adalah spesies yang tidak selalu terancam punah, namun perdagangannya harus dikontrol untuk menghindari pemanfaatan yang membahayakan kelangsungan hidupnya satwa yang termasuk kategori ini berdasarkan penelitian adalah Ular Sawa (Phyton curtus) dan Kucing Batu (Pardofelis marmorata). Appendix III adalah spesies yang dilindungi oleh paling sedikit satu negara dan pihak tersebut meminta bantuan CITES untuk mengendalikan perdagangannya satwa yang termasuk kategori ini berdasarkan penelitian adalah Musang (Paradoxurus hermaphrodites) (Risnandar, 2017).

Masyarakat Dayak Kanayant di Desa Lintah Betung Kecamatan Menyuke Kabupaten Landak memanfaatakan 32 jenis satwa untuk konsumsi. Sejumlah 32 jenis satawa tersebut, terdapat beberapa jenis satwa yang termasuk dalam daftar appendix I, appendix II dan appendix III. Appendix I adalah satwa yang terancam punah. Appendix II adalah spesies yang tidak selalu terancam punah, namun perdagangannya harus dikontrol untuk menghindari pemanfaatan yang membahayakan kelangsungan hidupnya. Appendix III adalah spesies yang dilindungi oleh paling sedikit satu negara dan pihak tersebut meminta bantuan CITES untuk mengendalikan perdagangannya. Dapat dilihat pada tabel 3 di bawah ini jenis satwa yang termasuk kedalam appenix I, appendix II, dan appendix III.

Tabel 2. Status Konservasi Satwa yang dimanfaatkan (Animals Conservation Status That Is Untilized)

\begin{tabular}{|c|c|c|c|c|c|}
\hline No & $\begin{array}{c}\text { Nama } \\
\text { Indonesia }\end{array}$ & Nama Ilmiah & Famili & $\begin{array}{c}\text { CITES } \\
\text { APPEND } \\
\text { ICE }\end{array}$ & IUCN \\
\hline 1 & Babi & Sus barbatus & Suidae & - & - \\
\hline 2 & Rusa & Cervus unicolor & Cervidae & - & DD \\
\hline 3 & Kelelawar & Pteropus admiralitatum & Pteropodidae & - & LC \\
\hline 4 & Terengiling & Manis javanica & Manidae & I & $\mathrm{CR}$ \\
\hline 5 & Tupai & Tupaia gracilis & Tupaiidae & - & LC \\
\hline 6 & Munsang & Paradoxurus hermaphroditud & Viverridae & III & $\mathrm{LC}$ \\
\hline 7 & Anjing Hitam & Canis lupus familiaris & Canidae & - & - \\
\hline 8 & Tikus sawah & Rattus argentiventer & Muridae & - & - \\
\hline 9 & Kucing hutan & Pardofelis marmorata & Felidae & II & LC \\
\hline 10 & Kijang & Muntiacus muntjak & Cervidae & - & LC \\
\hline 11 & Monyet & Macaca fascicularis & Hominoidea & - & $\mathrm{LC}$ \\
\hline 12 & Kelelawar & Pteropus admiralitatum & Pteropodidae & - & LC \\
\hline 13 & Kancil & Tragulus & Tragulidae & - & NT \\
\hline 14 & Kareo Padi & Amaurornis phoenicurus & Rallidae & - & - \\
\hline 15 & Ayam & Gallus gallus domesticus & Phasianidae & - & - \\
\hline 16 & Kalong & Pteropus vampyrus & Pteropodidae & - & LC \\
\hline 17 & Kodok sawah & Fejervarya cancivora & Ranidae & - & - \\
\hline 18 & Lele & Clarias batarchus & Clariidae & - & LC \\
\hline 19 & Gabus & Channa striata & Channidae & - & LC \\
\hline 20 & Ikan baung & Mystus nemurus & Bagridae & - & LC \\
\hline 21 & Ikan betook & Anabas testudineus & Anabantidae & - & - \\
\hline 22 & Ular pithon & Phyton curtus & Phytonidae & II & $\mathrm{LC}$ \\
\hline 23 & Labi-labi & Dongania subplana & Trionychidae & - & $\mathrm{LC}$ \\
\hline
\end{tabular}




\begin{tabular}{|c|c|c|c|c|c|}
\hline 24 & Kura-kura & Manouria emys & Trionychidae & - & $\mathrm{LC}$ \\
\hline 25 & Biawak & Varanus salvator & Varanidae & - & LC \\
\hline 26 & Ular & Ptyas korros & Serpentes & - & $\mathrm{LC}$ \\
\hline 27 & Udang & Macrobrachium rosenbergii & Pandalidae & - & - \\
\hline 28 & Kepiting & Parathelphusa convexa & Parathelphusidae & - & - \\
\hline 29 & Ulat sagu & Rhynchophorus ferruginesus & Curculionidae & - & - \\
\hline 30 & Tengkuyung & Helix pomatia & Helicidae & - & - \\
\hline 31 & Bekicot & Achatina fulica & Achatinidae & - & - \\
\hline 32 & Anjing & Canis lupus dingo & Canidae & - & - \\
\hline
\end{tabular}

Keterangan : LC: Least concearn; DD : Data Deficient; CR : Critically Endangered; NT : Near Threatened.

Berdasarkan status konservasi tabel 3 Satwa yang dimanfaatkan sebagai konsumsi sebanyak satu jenis satwa masuk ke dalam satwa yang terancam punah yaitu jenis terengiling dengan status Critically Endangered. Satwa yang termasuk ke dalam Critically Endangered adalah Harimau Sumatera, Badak Jawa, Badak Sumatera, Jalak Bali, Orangutan Sumatera, Elang Jawa, Trulek Jawa, dan Rusa Bawean.atau 2 langkah menuju kepunahan dan berdasarkan CITES APPENDICE masuk dalam golongan 1. Satwa yang termasuk kedalam golongan 1 adalah Gorila, Simpanse, dan Harimau.

\section{Kesimpulan}

Pemanfaatan satwa untuk kebutuhan konsumsi sebanyak 32 jenis satwa yang terdiri dari mamalia, aves, amfibi, pisces, reptil crustacea, insecta dan molusca. Hewan yang paling utama dimanfaatkan untuk konsumsi adalah kelas mamalia. Masyarakat Dayak Kanayant mengolah daging satwa dengan cara di goreng, dimasak kuah dan dibakar, kebanyakan masyarakat masih menggunakan peralatan tradisional untuk memasak daging maupun untuk berburu.

\section{Saran}

1. Mengingatkan kembali nilai-nilai luhur yang dimilki Suku Dayak Kanayant di Desa Lintah Betung untuk memperkecil kemungkinan kelangkaan hewan yang mereka butuhkan.

2. Kurangnya pengetahuan masyarakat di Desa Lintah Betung Kecamatan Menyuke Kabupaten Landak mengenai status perlindungan hewan sehingga diperlukan sosialisai mengenai status konservasi hewan kepada masyarakat.

\section{DAFTAR PUSTAKA}

Bebas WG. 2016. Penambahan Astaxanthim pada Pengencer Kuning Telur Berbagai Jenis Unggas Dapat Memproteksi Semen Babi Selama Penyimpanan.

Dewin VL, Anwari MS, Prayogo H. 2017. Kajian Masyarakat Dayak Seberuang di Desa Gurung Mali Kecamatan Tempunak Kabupaten Sintang.Fakultas Kehutanan Universitas Tanjungpura. Jurnal Hutan Lestari. Vol.5 (4) : 978-986

Dwi RH. 2011. Kearifan Lokal Dalam Perburuan Satwa Liar Suku Dayak Kenyah, di Taman Nasional Kayan Mentarang, Kalimantan Timur. Bogor Agrycultural University.

Heningsih M, Anwari MS, Yani A. 2018. Kajian Etnozoologi Untuk Obatobatan Masyarakat Dayak Belangin di Desa Mu'un Kecamatan Ngabang Kabupaten Landak. Fakultas 
Kehutanan Universitas Tanjungpura. Jurnal Hutan Lestari. Vol.6 (3) : 647653

Masyithah. 2016. Kajian Etnozoologi Hewan yang Dikonsumsi pada Komunitas Orang Rimba di Taman Nasional Bukit Duabelas Kabupaten Sorolangun. Fakultas Keguruan Ilmu Pendidikan Universitas Jambi. Jurnal Bio-site. Vol. 02 No. 2 : 1-50

Meijaard E, Sheil D, Nasi R, Augeri D, Rosenbaum B, Iskandar D, Setyawati P, Lammertink M, Rachmatika I, Wong A, Soehartono T, Stanley S, Gunawan T, dan O’Brien T. 2006. Hutan pasca pemanenan: Melindungi satwaliar dalam kegiatan hutan produksi di Kalimantan= life after logging: reconciling wildlife conservation and production forestry in Indonesian Borneo. Bogor: CIFOR.
Ngadri. 2018. Asal Usul Sejarah Dayak Kanayant Kalbar. (Online). https://delikkalbar.com/2018/04/14/as al-usul-sejarah-dayak-kanayantkalbar/. Diakses pada 14 April 2019.

Putri W N. 2009. Aktifitas Spesifik Katalase Jaringan Hati Tikus yang Diinduksi Hipoksia Hipobarik Akut Berulang. Fakultas Kedokteran Universitas Indonesia.

Risnandar C. 2018. Status Konservasi Ensiklopedi Jurnal. (Online). https://jurnalbumi.com/2014/4/8. Diakses pada 24 november 2018.

Rusmiati, Anwari MS, Tavita GE. 2018. Etnozoologi Masyarakat Dayak Bakati di Desa Seluas Kecamatan Seluas Kabupaten Bengkayang. Fakultas Kehutanan Universitas Tanjungpura. Jurnal Hutan Lestari. Vol. 6(3) : 594-604 